\section{International Scientific Journal Theoretical \& Applied Science}

p-ISSN: 2308-4944 (print) ｅ-ISSN: 2409-0085 (online)

Year: $2016 \quad$ Issue: 6 Volume: 38

Published: $30.06 .2016 \quad \underline{\text { http://T-Science.org }}$
Odina Azimjonovna Tursunova

Assistant of the chair of "Uzbek linguistics" of Andizhan State University, Andizhan, Uzbekistan tursunova_odina@mail.ru

SECTION 29. Literature. Folklore. Translation Studies.

\title{
PHONOPOETICS OF THE TEXT
}

Abstract: In this article we introduce the phonopoetics, the small progressive layer of linguopoetics. The article gives the opinions about the phonetic peculiarities of the speech, emotional - expressive functions of artistic literature and phonopoetics means of poems. Every linguopoetics analyzes demand to pay attention to the figure and meaning relations. Because, in the bottom of artistic text's form there is lead the meaning. The upper meaning and low meaning are retold. In the result the assimilation of the figure and meaning of artistic text are created.

Key words: Linguopoetics, phonopoetics, rhythm, melody, phragmatics, germenevtics, saadj, the differences of phonopoetic structure.

Language: English

Citation: Tursunova OA (2016) PHONOPOETICS OF THE TEXT. ISJ Theoretical \& Applied Science, 06 (38): 118-120.

Soi: http://s-o-i.org/1.1/TAS-06-38-24 Doi: crossef http://dx.doi.org/10.15863/TAS.2016.06.38.24

The language is not only the means of communication, but it is the great resource which is carried on the knowledge to the next descendent and made the emotional - esthetic feelings.

By the speech, one can make the men, laugh make them happy, and make them cry [7: p. 19]. That is why, in order to study the communicative unit of linguistic structure, it is very important to learn it's emotional - expressive finctions and connotative meaning. The emotional expressive functions of linguistic units to be realized with the help of artistic speech. As the result, the philological science the linguopoetics become to study the emotional expressive functions of artistic text [3: p. 9]. The linguopoetics inclusive of the poetics features of all structural units. By its resourcing studies, it divides into phonopoetics, morphopoetics, lexical poetics, synthetic poetics and derivopoetics.

As the general problems of linguopoetics, the lexical poetics, the poetics of the text, poetic stylistic, phonosemantics come to the field of linguistics. But the phonopoetics have not investigated thoroughly yet. It shows us that the theme is very necessary to solve in Uzbek literature.

As the other branches, the linguistics is progressing at every moment. Though, every subject relays on the theory of its own every time and creates new ways of subject. Like the phonostylistics and phonosemantics, the phonopoetics and linguopoetics are made from these sciences. $[9 ; 6]$
Phonopoetics investigate the literary description art, its music's soundings expressive features, the poem's art, the role of the sound and stress, the rhythm and the system of the sounds. The rhythm of poems are investigating in the linguistics as the object of the science. It has the rhythm and it is the base of the language. It shows us the importance of the poem's rhythm as in literature so in linguistics.

The sensitiveness of the poetic speech is united in the rhyme and melodious sound. German scientist Y.Yann considered as the poetry consists of the metrics rhythmic and the sound: "The poem is unique event, in the same time, the optic component, (to comprehension the text by seeing), acoustics and metrics component are included to it, and these three components make the sensual meanings," - he said [8; 10: p. 242-255].

Although, the phonopoetics is not investigated, most of linguists give a lot of information about this branch.

Aristotle in his "Poetics" gived the ideas about the phonetics units such as sound and rhythm [2: p. 20]. The arts including the sounds are given in "Funun ul-balog'a", of Shayx Akhmad ibn Hudaydod, in "Badoe us-sanoe" of Vosifiy.

A.Abdullayev in his "The expressiveness in Uzbek" wrote the information about it: "newaday's in Modern Uzbek there are such kind of expressiveness: 1) to pronounce the vowels strongly; 2) quantities stress; 3) germination. Below mentioned 
events have the peculiarities and features. So, the expressivenes has some meanings, such as strengthening, weakening, caress, loving. These meanings create the changing the sounds, the strengthening of the sounds, increase the sound and divide the word to the syllable" [1: p. 3].

All kind of linguopoetics analyze one should pay attention to the relation of form and meaning. In every text by the meaning "form" we should understand the difficult expression. The upper and lower meanings are introduced. In the result, the asymmetries of form and meaning are happened in the literary text.

In the analyzes of the literary text place and time are very important, if we stand near to the object as the time, it's meaning, essence and express make the relations to objectiveness. This problem, especially, in phonetic system is very important. Because, "in Turkic language's history the phonetics define as the difficult and confusion branch. It has real cause and serious one. The difficulties in investigating the historical phonetics connect with the spellings, but the spellings don't mention in any work until the middle of the XX century" [4: p. 25].

The actual phonetic language means can be analyzed from the sounds to the synthetic units.

The poetic speech phonetics may be the very important object of investigation. "The barmoq" poetical rhythm system are based on the quantity of the syllables, in spite of, it divides to the "turoq", intonation peculiarities the role of pause and a lot of arts connection create the phonopoetics, the connection pot of the phonetics and poetics. The phonetics is the investigation of poetic speech. But, while we analyze the phonetic peculiarities, we don't invent the phonopoetics features.

Besides of, the places of phonetic peculiarities which are used in poetic mentioned in writing, but has some hidden meanings. The built structure of poetics is the phonetic units.

The science, which is investigated the esthetic functions of language of the artistic speech what becomes very high authoritative branches of philology is the linguopoetics [5: p. 7]. As, every branches have their little layer, the upper layer of linguopoetics is the phonopoetics.

While, the phonopoetics are investigating as the branches, it has peculiar specific features and we should define the object of investigations. As the specific features we can count the formation of poetic work, logical and esthetic, expressive quality, melodically, tone, timbre, the rhythmic intonation and emotion peculiarities. Since that, truly these are the investigative object of phonetics.

At the same time the phonetic text are the reasons to pronounce as the people need. And this is belonged to the germenevtics. The function of the germenevtics is to remove before hand «the lacks of the speech and wrong pronunciation of the text». The function of germenevtics is to explain the comprehensive events of phenomenological analyze. Such interpretation gives the chance to find the important point's of the text.

The commentary and the analyze are demonstrated as the event and the result. The commentary begins when we appeal to the text. It is the first condition of the germenevtics. It means to confess to another variants of the analyze and substance.

To understand the text, the in terpreter should not stay away the events. It doesn't matter how to accept it. On the contrary, he strives to understand the meaning of the text. If he wants to interpret the text, he should connect it with the essence.

We should consider, while the interpretation or comprehension of something, one of the pieces are left. It comes across the speaking, talking and oral speech. Sometimes, during the speaking of the life of people, their happiness, proud and the fate, something is not spoke. Because, the speech cannot retell all the essence of these. And the feelings do not define in the oral speech. The essence of text, it's meaning, the traditions the intellectual degrees of subject, and thinking depend on speech. The aim of thinking to understand the world, it's being, and it's connection. To learn the other world and understand, firstly the author and character should understand itself.

The structural linguistics pay attention to the understanding the degrees of relations of the speech and language, it's colourness. That is why, the cognitive linguistics grows up the structural linguistics, it pays attention to the discursive sides.

In fact, the "soul" of the language is the discourse. All the social function, cumulative function, and emotional-expressive functions of the language reflect in discourse.

The emotional-expressive function of the artistic speech is mainly expressed with phonetic means and melody. Phonetic means are the main relevant characteristics of the artistic discourse, and the creator of the beauty of speech. Thus not only the lexical poetics part but also phono-poetics, morphopoetics, and syntactic poetics parts of the linguapoetics which study the emotional and aesthetic function of the certain language should became serious research objects. There are special expressemas which include such means as tonema, syllabema, and vowel harmony.

Expressemas serve to express the emotional state of the speaker in speech; to differentiate the type of the sentence by its aim; to express the gradation of the things and events, feature and characteristics, motions and states; to function artistic-aesthetic tasks.

The phonetic means, like the other poetic ones should characterize it's peculiarities and applies the charming speech. To understand and interpreter the 


\begin{tabular}{|c|c|c|c|c|c|c|}
\hline Impact Factor: & $\begin{array}{l}\text { ISRA (India) } \\
\text { ISI (Dubai, UAF } \\
\text { GIF (Australia) } \\
\text { JIF }\end{array}$ & $\begin{array}{l}=1.344 \\
=0.829 \\
=0.564 \\
=1.500\end{array}$ & $\begin{array}{l}\text { SIS (USA) } \\
\text { PИНЦ (Russia) } \\
\text { ESJI (KZ) } \\
\text { SJIF (Morocco) }\end{array}$ & $\begin{array}{l}=0.912 \\
=0.234 \\
=1.042 \\
=2.031\end{array}$ & $\begin{array}{l}\text { ICV (Poland) } \\
\text { PIF (India) } \\
\text { IBI (India) }\end{array}$ & $\begin{array}{l}=6.630 \\
=1.940 \\
=4.260\end{array}$ \\
\hline
\end{tabular}

phonetic speech are representated by the philological preparing of the (interpreter) researchers. Study the text, germenevtica serves to represent the phonetic units such as the distinctive, expressive function.

The phonopoetic peculiarities are the main means of creation «the azuz». Because, «the azuz» is based on the vowel harmony, open - close syllables. The ravii is the leader and necessary element of the rhyme. The rhyme and it's features, pronouciations relates to each other, and these features are in motion, this position gives the chauce to increase the opportunities of rhyme, to change the quality and to carry out of the monotone.

«The barmoq» rhythme is not marked by it's quantity of syllables but the division of the syllables in the line.

Making conclusion, we should name the functions of phonopoetics and germenevtics methods:
- phonetic means don't for the logic means, but do the function of the artistic - esthetic express; sounds;

- the poetic aim of the speaker defines the

- seethe saaj, rukn, rhythm and rhyme are represented by the phonetic peculiarities and they considers as the phonopoetic means;

- the «azuz» and «barmoq» poem system's researching object is the phonopoetic means;

- the role of the art «saaj» is very big. That is why, saaj makes the nazm in the phonetic sides;

- segmentation also has very important role in poem structure, so, gemination of poem, harmony, open and close syllable and changing the consonant relate to «hijjo».

\section{References:}

1. Abdullayev A (1987) O'zbek tilida ekspressilik ifodalashning sintaktik usuli. - Toshkent: Fan, 1987.

2. (2004) Arastu. Poetica. Axloqi kabir. Toshkent: Yangi asr avlodi, 2004.

3. Grigor'yev VP (1979) Poetica slova. -Moscow: Nauka, 1979.

4. Jumayev $\mathrm{T}$ (1997) Umar Boqiy asarlarining lisoniy xususiyatlari. Filol.fanlari nomzodi... diss. -Toshkent, 1997.

5. Yoldoshev M (2007) Badiiy. Matn va uning lingvopoetic tahlili asoslari. -Toshkent: Fan, 2007.

6. Qabilova Z (2008) O'zbek fonosemantik vositalari. Filol.fanlari nomzodi... diss. Toshkent, 2008.

7. Nurmonov A, Umarov A (2011) O'zlikni so'zdan topgan olim. Mahmudov Nizomiddin
Mamadaliyevich. -Toshkent: Bibliografiya. O’zME, 2011.

8. Stupak N (2016) Foneticheskiy component v obraznoy sisteme poeticheskogo proizvedeniya. Available:

http://www.portalus.ru/linguistics/rus.

(Accessed: 10.06.2016).

9. Haydarov AA (2008) Badiiy tasvirning fonostilistik vositalari: Filol.fanlari nomzodi...diss. -Toshkent, 2008.

10. Janning J (1979) Die Rekonstruktion der Gedihtgestalt aus der Struktur von Kleang und Rhytmus.-Muttersplache, Wiesbaden, 1979. pp. 242-255. 